\title{
Medium-term Impact of Conservation Agriculture on Soil Organic Carbon and Water Stable Aggregates in a Rainfed Hilly Agro-ecosystem
}

\author{
K. N. Mishra*, Bidyashree Tripathy, P. K. Roul and S. N. Dash \\ Dept. of Soil Science \& Agricultural Chemistry, Orissa University of Agriculture and Technology, Bhubaneswar, Odisha \\ (751 003), India
}

\section{Article History}

Manuscript No. AR1567

Received in $9^{\text {th }}$ April, 2016

Received in revised form $30^{\text {th }}$ May, 2016

Accepted in final form $4^{\text {th }}$ June, 2016

\section{Correspondence to}

${ }^{*} E$-mail: khiturajprav@yahoo.co.uk

\section{Keywords}

Tillage, SOC, bulk density, water stable aggregates, stratification ratio

\begin{abstract}
The impact of conservation agriculture production system (CAPS) on soil organic carbon, bulk density, water stable aggregates and dry season soil moisture content across the profile $(0-5,5-10$ and $10-20 \mathrm{~cm})$ was assessed at the end of the $3^{\text {rd }}$ cropping year in the rainfed agro-ecosystem under the hilly tracts of north Odisha. The treatment combinations are conventional tillage (CT) and minimum tillage (MT) with sole maize $(\mathrm{M})$ and inter cropmaize+cowpea $(\mathrm{M}+\mathrm{C})$ in main-plots during wet season and horse gram (H), Toria mustard (T) and no cover crop (NCC) in sub-plots during dry season. Surface accumulation and retention of soil organic matter (SOM) under MT decreased the bulk density (BD) by $3.4 \%, 2.6 \%$, increased the soil organic carbon (SOC) by $27.9 \%, 15.2 \%$, water stable macro-aggregates by $14.9 \%, 11.9 \%$, macro-aggregate $\mathrm{C}$ by $5.2 \%, 4.3 \%$ over the initial status in the top two layers $(0-5,5-10 \mathrm{~cm})$. Depletion of $\mathrm{SOM}$ induced by soil inversion under CT systems increased the BD $(+1.5 \%,+2.2 \%)$, decreased the SOC $(-9.8 \%,-15.7 \%)$ and macro-aggregates $(-5.3 \%,-5.7 \%)$. The pronounced effect of cover crops due to litter inputs was reflected on SOC $(+13.0 \%)$ and macro-aggregates $(+7.2 \%)$ in the surface layer of $0-5 \mathrm{~cm}$. Higher SOC stratification ratio observed in the soils under MT (1.73 to 1.79) indicated the effectiveness of MT in improving SOM accumulation. The study singles out SOC as the most dominant soil parameter affecting soil $\mathrm{BD}\left(\mathrm{r}=-0.85^{* *}\right)$, water stable macro-aggregates $\left(\mathrm{r}=0.90^{* *}\right)$, macro-aggregate $\mathrm{C}\left(\mathrm{r}=0.92^{* *}\right)$ and soil moisture $\left(\mathrm{r}=0.82^{* *}\right)$ in the surface layer.
\end{abstract}

\section{Introduction}

The natural resources under rainfed agro-ecosystem in the hilly terrains of North Odisha is very often vulnerable to degradation through loss of fertile top soils by water erosion, poor organic matter contents, mismanagement of land resources and changing climate, resulting a decline in soil productivity (Mohantyet al., 2015). Intensive tillage, residue removal and burning practised during the whole crop season accelerate soil erosion, environmental pollution, soil degradation and affects ecosystem functions. Sustainable crop production without any degradation of natural resources can be achieved through a set of crop-nutrient-water-landscape system management practice popularly known as conservation agriculture production system (CAPS) that involves minimal soil disturbance, a permanent soil cover, and ecologically viable crop rotations. A permanent soil cover, through the use of cover crops and crop residue mulch retention, combined with reduced tillage could be the best management practice for soil organic matter (SOM) restoration and control of erosion (Dube et al., 2012). The adoption of conservation tillage methods such as minimum cultivation and residue incorporation can reduce carbon emissions and enhance soil structural stability, thus reducing erosion risk (Hazarika et al., 2009). The increase in soil organic carbon reduces bulk density and increases water holding capacity and soil aggregate stability (Herencia et al., 2011). The proportions of waterstable aggregates in a soil often change very rapidly when tillage practices and crop rotations are modified (Kushwaha et al., 2004). Soil disturbance through tillage is a major cause of reduction in the number and stability of soil aggregates and subsequently SOM depletion (Six et al., 2002). Loss of soil aggregates after intensive tillage can de-protect and release SOM entrapped within and between aggregates, with the subsequent stimulation of SOM decomposition, in particular through the disruption of large macro-aggregates (Kabiri et al., 2015). Reduced tillage increases soil stability due to less physical disruption of aggregates, soil carbon may increase from greater protection inside aggregates and less exposure 
to oxygen, improve macro-porosity and thereby infiltration rates and soil water storage (Crittenden et al., 2015). Minimum tillage and residue application were associated with greater soil water content compared with conventional tillage without residue (Abdullah, 2014). These positive impacts of CAPS on soils encourage the scientists World over for adaptation of this technology, particularly in degraded rainfed agroecological environments to achieve sustainable and intensive crop production.

The favourable influence of CAPS on SOM and some major soil physical properties is poorly documented for tropical agro-ecosystems of India. Such information is completely lacking from the undulating hilly terrains under the North Central Plateau zone of Odisha. Keeping these facts in the backdrop, a field experiment with maize based CAPS has been established at Regional Research and Technology Transfer Station, Kendujhar, Odisha, during 2011. The objective of the present study is to assess the impact of CAPS involving tillage practices (minimum tillage and conventional tillage), cropping systems (maize sole and maize+cowpea intercrop) and both with and without cover crops (horsegram and toria mustard) on soil organic carbon, bulk density, water stable aggregates and dry season moisture content across the profile at the end of third cropping cycle.

\section{Materials and Methods}

The study area is located at Regional Research and Technology Transfer Station of Orissa University of Agriculture and Technology, Kendujhar (2050' 55.38' N, 85 34' 30.61'" $\mathrm{E}$ and $499 \mathrm{~m}$ amsl), Odisha, India. The climate is hot and sub humid with mean annual rainfall of $1473 \mathrm{~mm}$. The soil developed from colluvial alluvial deposits in a piedmont plain belongs to Fluventic Haplustepts with sandy clay loam surface texture. A long term on-station experiment was initiated during 2011-12 and the present study was after completion of $3^{\text {rd }}$ cropping cycle (2013-14). In the $1^{\text {st }}$ season (June-October) of cropping cycle, four treatments viz. CT-M: Conventional tillage with sole maize (Zea mays); CT-M+C: Conventional tillage with maize+cowpea (Vigna unguiculata); MT-M: Minimum tillage with sole maize; MT-M+C: Minimum tillage with maize+cowpea were applied as main plot treatments in triplicate. In the $2^{\text {nd }}$ season (November-January) of cropping cycle, residual effects of four main plot treatments and direct effects of cover crop treatments (sub-plot) were tested in a split plot design. The sub-plot treatments are NCC: no cover crop (fallow); H: Horse gram (Macrotyloma uniflorum) as a cover crop; T: Toria mustard (Brassica juncea) as a cover crop. The conventional tillage (CT) involves three mould board ploughing without residue to a depth of $20-25 \mathrm{~cm}$ and in minimum tillage (MT), one shallow disking is done up to a depth of $10 \mathrm{~cm}$ with addition of chopped main crop (maize, cowpea) and cover crop (Horse gram, Toria mustard) biomass as surface residues. Soil samples $(0-5,5-10,10-20 \mathrm{~cm})$ collected initially (2011) and at the end of $3^{\text {rd }}$ cropping cycle (2014) were analyzed for determination of water stable aggregates (Kemper and Rosenau, 1986), organic carbon from bulk soil and from water stable aggregates (Walkley and Black, 1934). Undisturbed core samples from each layer were collected with a core sampler (5.0 $\mathrm{cm}$ diameter) for determination of soil bulk density (Blake et al., 1986) dry season gravimetric moisture content (Grossman and Reinsch, 2002).

\section{Results and Discussion}

\subsection{Bulk density (BD)}

Practice of minimum tillage (MT) three years in a row, reduced the soil BD (Table 1 ) in the tune of $3.4 \%$ and $2.6 \%$ over the initial values $\left(1.32\right.$ and $\left.1.37 \mathrm{Mg} \mathrm{m}^{-3}\right)$ in $0-5$ and $5-10 \mathrm{~cm}$ depths, respectively, whereas, these soils under conventional tillage (CT) registered higher $\mathrm{BD}(+1.5 \%,+2.2 \%)$. Cover cropping $(\mathrm{H}, \mathrm{T})$ also lowered the soil BD by 1.3 and $1.0 \%$ in the depth ranges of $0-5 \mathrm{~cm}$ and $5-10 \mathrm{~cm}$, respectively over the soil under NCC (1.32 and 1.38 $\left.\mathrm{Mg} \mathrm{m}^{-3}\right)$. The bottom layer (10-20 $\mathrm{cm})$ did not exhibit any significant variation in soil BD. The

Table 1: Effect of tillage and cropping systems on bulk density (BD) and soil organic carbon (SOC)

\begin{tabular}{|c|c|c|c|c|c|c|c|}
\hline \multirow{2}{*}{$\begin{array}{l}\text { Treat- } \\
\text { ments }\end{array}$} & \multicolumn{3}{|c|}{$\mathrm{BD}\left(\mathrm{Mg} \mathrm{m}^{-3}\right)$} & \multicolumn{3}{|c|}{$\mathrm{SOC}\left(\mathrm{g} \mathrm{kg}^{-1}\right)$} & \multirow{2}{*}{$\begin{array}{l}\text { Abbre- } \\
\text { viation }\end{array}$} \\
\hline & $\begin{array}{l}0-5 \\
\mathrm{~cm}\end{array}$ & $\begin{array}{c}5-10 \\
\mathrm{~cm}\end{array}$ & $\begin{array}{c}10-20 \\
\mathrm{~cm}\end{array}$ & $\begin{array}{l}0-5 \\
\mathrm{~cm}\end{array}$ & $\begin{array}{c}5-10 \\
\mathrm{~cm}\end{array}$ & $\begin{array}{c}10-20 \\
\mathrm{~cm}\end{array}$ & \\
\hline \multicolumn{8}{|c|}{ Main plot } \\
\hline CT-M & 1.36 & 1.41 & 1.46 & 5.78 & 5.21 & 4.67 & $\begin{array}{l}\text { CT: Con- } \\
\text { ventional } \\
\text { tillage }\end{array}$ \\
\hline $\begin{array}{l}\mathrm{CT}- \\
\mathrm{M}+\mathrm{C}\end{array}$ & 1.32 & 1.39 & 1.45 & 6.51 & 5.64 & 4.80 & $\begin{array}{l}\text { MT: } \\
\text { Minimum }\end{array}$ \\
\hline MT-M & 1.28 & 1.34 & 1.45 & 8.36 & 7.09 & 4.84 & tillage \\
\hline $\begin{array}{l}\text { MT- } \\
\mathrm{M}+\mathrm{C}\end{array}$ & 1.27 & 1.33 & 1.45 & 9.08 & 7.74 & 5.08 & M: Maize \\
\hline $\begin{array}{l}\text { LSD } \\
(0.05)\end{array}$ & 0.04 & 0.02 & NS & 0.48 & 0.47 & NS & $\begin{array}{l}\text { C: } \\
\text { Cowpea }\end{array}$ \\
\hline \multicolumn{8}{|c|}{ Sub-plot } \\
\hline $\mathrm{NCC}$ & 1.32 & 1.38 & 1.46 & 6.88 & 6.04 & 4.76 & NCC: \\
\hline $\mathrm{H}$ & 1.30 & 1.36 & 1.45 & 7.99 & 6.70 & 4.93 & $\begin{array}{l}\text { No cover } \\
\text { crop }\end{array}$ \\
\hline $\mathrm{T}$ & 1.31 & 1.36 & 1.45 & 7.43 & 6.52 & 4.86 & $\begin{array}{l}\text { H: Horse- } \\
\text { gram }\end{array}$ \\
\hline $\begin{array}{l}\text { LSD } \\
(0.05)\end{array}$ & 0.01 & 0.01 & NS & 0.32 & 0.27 & NS & $\begin{array}{l}\text { T: } \\
\text { Mustard }\end{array}$ \\
\hline Initial & 1.32 & 1.37 & 1.44 & 6.82 & 6.44 & 4.72 & \\
\hline
\end{tabular}


overall reduction of soil BD under MT systems with cover crops are restricted to top layers of $0-5 \mathrm{~cm}$ and $5-10 \mathrm{~cm}$ and this decrease is likely to be a reflection of considerable increase in SOM content induced by accumulation of litter inputs over the years on the soil surface (Arvidson, 1998; Fengyun et al., 2011). The higher BD in the top layer under CT systems may be attributed to the loss of finer particles induced by water erosion and low SOM leading to less aggregation (Lafond et al., 2011). The significant negative correlation of SOC with BD $\left(-0.85^{* *}\right.$ and $\left.-0.89^{* *}\right)$ in the layers of $0-5$ and $5-10 \mathrm{~cm}$, respectively justifies the favourable influence of SOM on soil BD.

\subsection{Water stable aggregates}

Aggregate measurement is very often used as surrogates of the complex soil matrix for studies of soil organic matter dynamics.

\subsubsection{Macro-aggregates $(>0.25 \mathrm{~mm})$}

The soils under MT exhibited significant increase macroaggregates proportion in $0-5 \mathrm{~cm}$ and $5-10 \mathrm{~cm}$ layers and the gain was in the tune of $14.9 \%$ and $11.9 \%$ (Table 2), respectively, over the initial values $(58.2 \%, 52.9 \%)$. Soils under CT in these

\begin{tabular}{|c|c|c|c|c|c|c|c|}
\hline \multirow[t]{2}{*}{$\begin{array}{l}\text { Treat- } \\
\text { ments }\end{array}$} & \multicolumn{3}{|c|}{$\begin{array}{l}\text { WSA }(>0.25 \mathrm{~mm}) \\
\text { Macro-aggregates }\end{array}$} & \multicolumn{3}{|c|}{$\begin{array}{l}\text { WSA }(0.053-0.25 \\
\mathrm{mm}) \\
\text { Micro-aggregates }\end{array}$} & \multirow[t]{2}{*}{$\begin{array}{l}\text { Abbre- } \\
\text { viation }\end{array}$} \\
\hline & $\begin{array}{l}0-5 \\
\mathrm{~cm}\end{array}$ & $\begin{array}{c}5-10 \\
\mathrm{~cm}\end{array}$ & $\begin{array}{c}10-20 \\
\mathrm{~cm}\end{array}$ & $\begin{array}{l}0-5 \\
\mathrm{~cm}\end{array}$ & $\begin{array}{c}5-10 \\
\mathrm{~cm}\end{array}$ & $\begin{array}{c}10-20 \\
\mathrm{~cm}\end{array}$ & \\
\hline \multicolumn{8}{|c|}{ Main plot } \\
\hline CT-M & 54.5 & 48.7 & 42.1 & 19.5 & 21.3 & 23.4 & $\begin{array}{l}\text { CT: Con- } \\
\text { ventional } \\
\text { tillage }\end{array}$ \\
\hline $\begin{array}{l}\mathrm{CT}- \\
\mathrm{M}+\mathrm{C}\end{array}$ & 55.7 & 50.8 & 43.6 & 17.3 & 18.7 & 21.7 & $\begin{array}{l}\text { MT: } \\
\text { Minimum }\end{array}$ \\
\hline MT-M & 64.9 & 58.5 & 46.1 & 15.8 & 17.1 & 20.7 & tillage \\
\hline $\begin{array}{l}\text { MT- } \\
\mathrm{M}+\mathrm{C}\end{array}$ & 68.9 & 59.8 & 46.0 & 13.9 & 15.7 & 20.0 & M: Maize \\
\hline $\begin{array}{l}\text { LSD } \\
(0.05)\end{array}$ & 4.39 & 5.32 & NS & 1.75 & 1.76 & NS & $\begin{array}{l}\text { C: } \\
\text { Cowpea }\end{array}$ \\
\hline \multicolumn{8}{|c|}{ Sub-plot } \\
\hline $\mathrm{NCC}$ & 58.2 & 52.5 & 42.9 & 17.4 & 19.2 & 21.9 & NCC: \\
\hline $\mathrm{H}$ & 63.3 & 55.8 & 45.7 & 16.0 & 17.3 & 20.9 & $\begin{array}{l}\text { No cover } \\
\text { crop }\end{array}$ \\
\hline $\mathrm{T}$ & 61.6 & 55.1 & 44.9 & 16.5 & 18.1 & 21.6 & $\begin{array}{l}\text { H: Horse- } \\
\text { gram }\end{array}$ \\
\hline $\begin{array}{l}\text { LSD } \\
(0.05)\end{array}$ & 3.17 & NS & NS & NS & NS & NS & $\begin{array}{l}\mathrm{T}: \\
\text { Mustard }\end{array}$ \\
\hline Initial & 58.2 & 52.8 & 44.7 & 16.2 & 18.1 & 19.6 & \\
\hline
\end{tabular}

two top layers exhibited a reduction of macro-aggregates by $5.3 \%$ and $5.7 \%$. There was no significant variation in macroaggregates in the deeper layer of $10-20 \mathrm{~cm}$. Treatments with cover crops elevated the status of macro-aggregates in the tune of $7.2 \%$ and $4.9 \%$ in the top two layers over NCC at the end of the $3^{\text {rd }}$ cropping year.

\subsubsection{Micro-aggregates $(0.053-0.25 \mathrm{~mm})$}

The proportion of micro-aggregates under MT soils were distinctly reduced and the reduction was in the tune of $14.8 \%$ and $14.5 \%$ in $0-5 \mathrm{~cm}$ and $5-10 \mathrm{~cm}$ layers (Table 2), respectively over the initial status $(17.7 \%$ and $19.2 \%)$. The concomitant increase of micro-aggregates in the soils under CT treatments was $5.9 \%$ and $4.3 \%$ for the top two layers. The bottom layers $(10-20 \mathrm{~cm})$ of both MT and CT exhibited no noticeable variation in the proportion of micro-aggregates. Treatments with cover crops could not influence the status of micro-aggregates much.

The higher proportion of macro-aggregates $(>0.25 \mathrm{~mm})$ concomitant with lower proportion of micro-aggregates $(0.053$ $0.25 \mathrm{~mm})$ observed in the top soil layers $(0-5$ and $5-10 \mathrm{~cm})$ under MT is related to reduced physical impact leading to lower aggregate turnover rates. Intensive disturbance of the top layer under $\mathrm{CT}$, in contrast, disrupts macro-aggregates ( $\mathrm{Six}$ et al., 2000a; Zotarelli et al., 2007). Again, the higher inputs of fresh organic matter in MT with cover crops induces increased microbial activity and production of microbial binding agents leading to the formation of higher macro-aggregate in the top two soil layers (Mikha and Rice, 2004; Jacobs et al., 2009). The strong positive correlation of SOC with macro-aggregates in the top two layers $\left(\mathrm{r}=0.9^{* *}\right.$ and $\left.0.76^{* *}\right)$ indicates the significance of SOM in formation of macro-aggregates.

\subsection{Gravimetric water content (w)}

The gravimetric water content $(\mathrm{w})$ across the soil profile differed significantly among the sampling time, registering higher values at sowing that went on decreasing during harvesting time of cover crops. The surface layer $(0-5 \mathrm{~cm})$ under MT treatments exhibited significantly higher water contents at sowing (16.5\%) compared to that of CT treatments (14.7\%). There was no significant variation in water contents in the surface layer during harvesting (Table 3). The water contents in 5-10 cm layer and 10-20 cm layer did not change significantly among treatments during sampling times. However, an increase in overall water contents across the profile was observed irrespective of treatments and sampling time.

Beneficial effects of crop residues maintenance on the soil surface under conservation tillage include increased water conservation and soil aggregation (Hubbard et al., 2013). In the dry period (Rabi season), the amount of water in the 


\begin{tabular}{|c|c|c|c|c|c|c|c|}
\hline \multirow[t]{2}{*}{$\begin{array}{l}\text { Treat- } \\
\text { ments }\end{array}$} & \multicolumn{3}{|c|}{$\begin{array}{l}\text { At sowing of } \\
\text { cover crops }\end{array}$} & \multicolumn{3}{|c|}{$\begin{array}{l}\text { At harvesting of } \\
\text { cover crops }\end{array}$} & \multirow[t]{2}{*}{$\begin{array}{l}\text { Abbre- } \\
\text { viation }\end{array}$} \\
\hline & $\begin{array}{l}0-5 \\
\mathrm{~cm}\end{array}$ & $\begin{array}{c}5-10 \\
\mathrm{~cm}\end{array}$ & $\begin{array}{c}10-20 \\
\mathrm{~cm}\end{array}$ & $\begin{array}{l}0-5 \\
\mathrm{~cm}\end{array}$ & $\begin{array}{c}5-10 \\
\mathrm{~cm}\end{array}$ & $\begin{array}{c}10-20 \\
\mathrm{~cm}\end{array}$ & \\
\hline \multicolumn{8}{|c|}{ Main plot } \\
\hline CT-M & 14.7 & 15.5 & 16.3 & 7.3 & 7.8 & 8.1 & $\begin{array}{l}\text { CT: Con- } \\
\text { ventional } \\
\text { tillage }\end{array}$ \\
\hline $\begin{array}{l}\mathrm{CT}- \\
\mathrm{M}+\mathrm{C}\end{array}$ & 14.6 & 15.7 & 16.4 & 7.5 & 7.8 & 8.1 & $\begin{array}{l}\text { MT: } \\
\text { Minimum }\end{array}$ \\
\hline MT-M & 16.2 & 17.0 & 17.3 & 7.8 & 8.5 & 9.0 & tillage \\
\hline $\begin{array}{l}\text { MT- } \\
\mathrm{M}+\mathrm{C}\end{array}$ & 16.7 & 17.2 & 17.4 & 7.9 & 8.7 & 9.2 & M: Maize \\
\hline $\begin{array}{l}\text { LSD } \\
(0.05)\end{array}$ & 1.69 & NS & NS & NS & NS & NS & $\begin{array}{l}\text { C: } \\
\text { Cowpea }\end{array}$ \\
\hline \multicolumn{8}{|c|}{ Sub-plot } \\
\hline $\mathrm{NCC}$ & 15.3 & 16.0 & 16.5 & 7.4 & 7.9 & 8.4 & NCC: \\
\hline $\mathrm{H}$ & 15.8 & 16.5 & 17.1 & 7.8 & 8.4 & 8.7 & $\begin{array}{l}\text { No cover } \\
\text { crop }\end{array}$ \\
\hline $\mathrm{T}$ & 15.6 & 16.5 & 17.0 & 7.7 & 8.3 & 8.6 & $\begin{array}{l}\text { H: Horse- } \\
\text { gram }\end{array}$ \\
\hline $\begin{array}{l}\text { LSD } \\
(0.05)\end{array}$ & NS & NS & NS & NS & NS & NS & $\begin{array}{l}\text { T: } \\
\text { Mustard }\end{array}$ \\
\hline Initial & 14.3 & 15.0 & 16.0 & 7.3 & 7.6 & 7.8 & \\
\hline
\end{tabular}

soil reduce gradually irrespective of tillage practices and soil layers as rainfall do not influence soil water pattern. Tillage reduction in association with residue retention significantly increased the moisture contents in the surface layers mainly due to large increase in SOC (Daraghmeh et al., 2009). Soil disturbance can also lead to a less stable pore system and pore aggregate development that reduce soil moisture contents and regular tillage also enhances direct evaporation of water from soil surface (Guto et al., 2012). The role of SOM on soil moisture contents in the surface layer is justified by significant positive correlation of SOC with water content during sowing $\left(\mathrm{r}=0.82^{* *}\right)$.

\subsection{Soil organic carbon (SOC)}

The SOC contents under MT increased significantly $(+27.9 \%$ and $+15.2 \%$ ) over the initial status of 6.82 and $6.44 \mathrm{~g} \mathrm{~kg}^{-1}$ in the top two layers of $0-5$ and $5-10 \mathrm{~cm}$ (Table 1). A reduction of SOC (-9.8\% and $-15.7 \%)$ was observed in CT treatments for the same layers. The contribution of cover crops to SOC pool, in the tune of $13.0 \%$ and $2.6 \%$ over NCC $\left(6.88\right.$ and $6.06 \mathrm{~g} \mathrm{~kg}^{-}$ ${ }^{1}$ ), was also observed in the top two layers. The SOC contents under both $\mathrm{CT}$ and MT treatments did not show any significant variations in the deeper layer of $10-20 \mathrm{~cm}$.
Significant elevation of SOC in soils under MT with cropping systems in the top two layers is attributed to greater buildup of residue input (6.0 to $6.5 \mathrm{tha}^{-1}$ of biomass) as well as lower biological oxidation due to less tillage induced soil inversion. Higher SOC contents due to absence of soil redistribution were also observed by Hel et al., 2009; Jemai et al., 2013. Again reduced physical impacts in MT increased the aggregate stability resulting in lower aggregate turn over, therefore improved physical protection of aggregate SOC from decomposition and thus higher SOC stocks. The soils under CT, in contrast, exhibited higher degradation of macroaggregate induced by intense soil disturbances exposing the formerly incorporated SOC stocks to microbial decomposition (Tan et al., 2007) in the top layers. Protection of SOC because of higher proportion of macro-aggregates under MT systems also corroborates the findings of Plaza-Bonilla et al. (2013).

\subsection{Water stable aggregate carbon}

The distribution of water stable aggregate carbon across the profile is presented (Table 4). Adoption of MT increased the macro-aggregate carbon by $5.2 \%$ and $4.3 \%$ over the initial status (13.88 and $\left.11.12 \mathrm{~g} \mathrm{~kg}^{-1}\right)$ in the layers of $0-5 \mathrm{~cm}$ and

Table 4: Effect of tillage and cropping systems on water stable aggregate (WSA) carbon $\left(\mathrm{g} \mathrm{kg}^{-1}\right)$

\begin{tabular}{|c|c|c|c|c|c|c|c|}
\hline \multirow[t]{2}{*}{$\begin{array}{l}\text { Treat- } \\
\text { ments }\end{array}$} & \multicolumn{3}{|c|}{$\begin{array}{l}\text { Macro-aggregates } \\
(>0.25 \mathrm{~mm}) \text { carbon }\end{array}$} & \multicolumn{3}{|c|}{$\begin{array}{c}\text { Micro-aggregates } \\
(0.053-0.25 \mathrm{~mm}) \\
\text { carbon }\end{array}$} & \multirow[t]{2}{*}{$\begin{array}{l}\text { Abbre- } \\
\text { viation }\end{array}$} \\
\hline & $\begin{array}{l}0-5 \\
\mathrm{~cm}\end{array}$ & $\begin{array}{c}5-10 \\
\mathrm{~cm}\end{array}$ & $\begin{array}{c}10-20 \\
\mathrm{~cm}\end{array}$ & $\begin{array}{l}0-5 \\
\mathrm{~cm}\end{array}$ & $\begin{array}{c}5-10 \\
\mathrm{~cm}\end{array}$ & $\begin{array}{c}10-20 \\
\mathrm{~cm}\end{array}$ & \\
\hline \multicolumn{8}{|c|}{ Main plot } \\
\hline CT-M & 11.48 & 9.70 & 10.10 & 8.13 & 7.44 & 7.42 & $\begin{array}{l}\text { CT: Con- } \\
\text { ventional } \\
\text { tillage }\end{array}$ \\
\hline $\begin{array}{l}\mathrm{CT}- \\
\mathrm{M}+\mathrm{C}\end{array}$ & 12.73 & 10.02 & 10.51 & 8.56 & 7.68 & 7.51 & $\begin{array}{l}\text { MT: Min- } \\
\text { imum till- }\end{array}$ \\
\hline MT-M & 14.23 & 11.58 & 9.91 & 9.27 & 8.79 & 6.76 & age \\
\hline $\begin{array}{l}\text { MT- } \\
\mathrm{M}+\mathrm{C}\end{array}$ & 14.87 & 11.70 & 10.20 & 9.71 & 9.06 & 6.66 & M: Maize \\
\hline $\begin{array}{l}\text { LSD } \\
(0.05)\end{array}$ & 1.23 & 1.53 & NS & 1.08 & 1.18 & NS & $\begin{array}{l}\text { C: } \\
\text { Cowpea }\end{array}$ \\
\hline \multicolumn{8}{|c|}{ Sub-plot } \\
\hline $\mathrm{NCC}$ & 12.31 & 10.43 & 9.96 & 8.30 & 7.98 & 7.01 & NCC: \\
\hline $\mathrm{H}$ & 14.14 & 10.96 & 10.35 & 9.50 & 8.43 & 7.18 & $\begin{array}{l}\text { No cover } \\
\text { crop }\end{array}$ \\
\hline $\mathrm{T}$ & 13.53 & 10.87 & 10.23 & 8.95 & 8.33 & 7.08 & $\begin{array}{l}\text { H: Hor- } \\
\text { segram }\end{array}$ \\
\hline $\begin{array}{l}\text { LSD } \\
(0.05)\end{array}$ & 0.58 & NS & NS & 0.48 & NS & NS & $\begin{array}{l}\mathrm{T}: \\
\text { Mustard }\end{array}$ \\
\hline Initial & 13.88 & 11.12 & 10.24 & 9.22 & 8.32 & 7.48 & \\
\hline
\end{tabular}


5-10 cm, respectively. The concomitant decrease in macroaggregate carbon in the top two layers under CT were $12.8 \%$ and $10.1 \%$. Growing of cover crops enhanced the macroaggregate carbon only in $0-5 \mathrm{~cm}$ layer and the gain was in the tune of $12.1 \%$ over NCC $\left(12.31 \mathrm{~g} \mathrm{~kg}^{-1}\right)$. Soils under MT also exhibited higher micro-aggregate carbon in the top two layers $(+3.0 \%$ and $+7.0 \%)$ over the initial status. The same layers under CT decreased the micro-aggregate carbon by $10.0 \%$ and $9.1 \%$ after $3^{\text {rd }}$ cropping year. Cover cropping elevated the micro-aggregate carbon contents by $13.3 \%$ over NCC $(8.3 \mathrm{~g}$ $\mathrm{kg}^{-1}$ ) in surface layer of $0-5 \mathrm{~cm}$ only.

The elevated macro-aggregate $\mathrm{C}$ in soils under MT, in the current study, is related to the physical protection of labile SOC within macro-aggregates from microbial decomposition due to higher litter inputs and lower soil disturbances (PlazaBonilla et al., 2013). The higher micro-aggregate C in MT soils are also related to greater buildup of SOM that facilitates more organic matter binding micro-aggregates (Kushwaha et al., 2001).Intense physical impacts in CT soils disrupt the $\mathrm{C}$ enriched macro-aggregates and expose them for microbial decomposition (Six et al., 2000a). Influence of SOC on aggregate carbon was evidenced by significant positive correlation of SOC with macro-aggregates $\mathrm{C}\left(\mathrm{r}=0.92^{* *}, 0.84^{* *}\right)$ and micro-aggregates $\mathrm{C}\left(\mathrm{r}=0.83^{* *}, 0.85^{* *}\right)$ in the top two layers.

\subsection{SOC stratification ratio}

Plant residue placement is of importance to the depth distribution of SOM (soil organic matter) in the soil profile, because plant residues contribute greatly to subsequent SOM formation. Therefore, stratification of SOM fractions has been suggested as an indicator of soil quality in different agroecological zones, because surface SOM is essential to erosion control, conservation of nutrients, water infiltration, and other important soil functions (Melero et al., 2012). In the present study, the SOC stratification ratios were calculated from SOC stocks at $0-5 \mathrm{~cm}$ divided by those at $10-20 \mathrm{~cm}$ (Figure 1). Higher SOC stratification ratio observed in the soils under MT

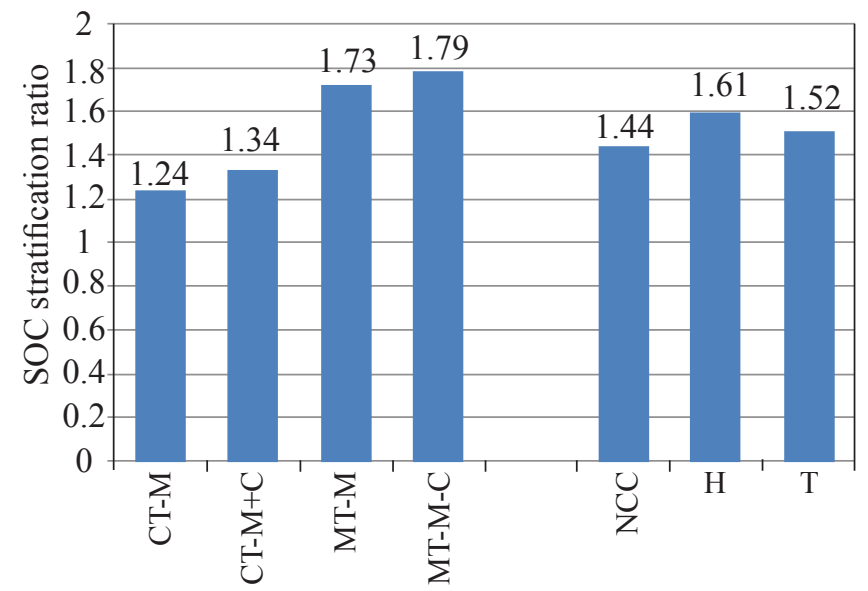

Figure 1: SOC stratification ratio as influenced by tillage and cropping systems
(1.73 to 1.79) indicated the effectiveness of MT in improving SOM accumulation and biological status of the surface layers, whereas the lower stratification ratio in CT (1.24 to 1.34) soils are related to even depth distribution of SOC as a result of intense soil disturbances (Franzluebbers, 2002).

\section{Conclusion}

The increased SOM contents under CAPS of minimum tillage with cropping systems contributed significantly in lowering soil bulk density and enhancing macro-aggregates, SOC, aggregate $\mathrm{C}$ in the top soil layers besides improving the dry season moisture contents. The greater SOC stratification ratio under minimum tillage could thus be considered as a good indicator of an improvement of soil properties, and confirms the benefits associated with the long-term application of this management system in the rainfed hilly agro-ecosystem of North Odisha.

\section{Acknowledgement}

The study was supported by research project SMARTS (Sustainable Management of Agro-ecological Resources for Tribal Societies), an Orissa University of Agriculture and Technology (Odisha, India) and University of Hawaii, Manoa (USA) collaborative programme. The logistics and technical support provided during the research are duly acknowledged.

\section{References}

Abdullah,A.S., 2014. Minimum tillage and residue management increase soil water content, soil organic matter and canola seed yield and seed oil content in the semiarid areas of Northern Iraq. Soil and Tillage Research 144, 150-155.

Arvidson, J., 1998. Influence of soil texture and organic matter content on bulk density, air content, compression index and crop yield in field and laboratory compression experiments. Soil and Tillage Research 4, 159-170.

Blake, G.R., Hartge, K.H., 1986. Bulk density. In: Klute, A. (Ed.), Methods of Soil Analysis. Part 1: Physical and mineralogical methods, $2^{\text {nd }}$ edition. : Agronomy Monograph No. 9. Soil Science Society of America. Madison, Wisconsin, 363-375.

Crittenden, S.J., Poot, N., Heinen, M., Balen, D.J.M. van, Pulleman, M.M., 2015. Soil physical quality in contrasting tillage systems in organic and conventional farming. Soil and Tillage Research 154, 136-144.

Daraghmeh,O.A., Jensen, J.R., Petersen, P.T., 2009. Soil structure stability under conventional and reduced tillage in a sandy loam.Geoderma150, 64-71.

Dube, E., Chiduza, C., Muchaonyerwa, P., 2012. Conservation agriculture effects on soil organic matter on a Haplic Cambisol after four years of maize-oat and maize- 
grazing vetch rotations in South Africa. Soil and Tillage Research 12, 21-28.

Fengyun, Z., WuPute, Xining, Z., Xuefeng, C., 2011. ReviewThee ffects of no-tillage practice on soil physical properties. A frican Journal of Biotechnology 10(77), 17645-17650.

Franzluebbers, A.J., 2002. Soil organic matter stratification ratio as an indicator of soil quality. Soil and Tillage Research 66, 95-106.

Grossman, R.B., Reinsch, T.G., 2002. Bulk density and linear extensibility. In: Dane, J.H.,Topp, G.C. (Eds.), Methods of Soil Analysis. Part 4. Agronomy Monograph vol. 5.Soil Science Society of America, Madison, Wisconsin, 201-225.

Guto, S.N., Ridder, N. de., Giller, K.E., Pypers, P., Vanlauwe, B., 2012. Minimum tillage and vegetative barrier effects on crop yields in relation to soilwater content in the Central Kenya high lands. Field Crops Research 132, 129-138.

Hazarika, S., Parkinson, R., Bol, Dixon, L., Russell, P., Donovan, S., Allen, D., 2009. Effect of tillage system and straw management on organic matter dynamics. Agronomy for Sustainable Development 29, 525-533.

Hel, J., Kuhn, N.J., Zhang, X.M., Zhang, X.R., Li, H.W., 2009. Effects of 10 years of conservation tillage on soil properties and productivity in the farming-pastoralecotone of Inner Mongolia. China. Soil Use and Management 25, 201-209.

Herencia, J.F., Garcta-Galavts, P.A., Maqueda, C., 2011. Long-term effect of organic and mineral fertilization on soil physical properties under green house and outdoor management practices. Pedosphere 21(4), 443-453.

Hubbard, Robert K., Strickl and Timothy, C., Phatak, S., 2013. Effects of cover crop systems on soil physical properties and carbon/nitrogen relationships in the coastal plain of southeastern USA. Soil and Tillage Research 126, 276-283.

Jacobs, A., Rauber, R., Ludwig, B., 2009. Impact of reduced tillage on carbon and nitrogen storage of two HaplicLuvisols after 40 years. Soil and Tillage Research102, 158-164.

Jemai, I., Aissa, N.B., Guirat, S.B., Ben-Hammouda, M., Gallali, T., 2013. Impact of three and seven years of notillage on the soil water storage, in the plant root zone, under a dry sub-humid Tunisian climate, Soil and Tillage Research 126, 26-33.

Kabiri, V., Raiesi, F., Ghazavi, Ali, M., 2015. Six years of different tillage systems affected aggregate-associated SOM in a semi-arid loam soil from Central Iran. Soil and Tillage Research 154, 114-125.
Kemper, W., Rosenau, R., 1986. Aggregate stability andsize distribution. In: Klute, A. (Ed), Methods of Soil Analysis, Part I: Physical and mineralogical methods, $2^{\text {nd }}$ edition, Agronomy Monographs, 9. Soil Science Society of America. Madison, Wisconsin, 425-442.

Kushwaha, C.P., Tripathi, S.K., Singh, K.P., 2001.Soil organic matter and water-stable aggregates under different tillage and residue conditions in a tropical dryland agroecosystem. Applied Soil Ecology 16, 229-241.

Lafond, Guy, P., Fran Walley, F., May, W.E., Holzapfel, C.B., 2011. Long term impact of no-till on soil properties and crop productivity on the Canadian prairies. Soil and Tillage Research 117, 110-123.

Melero, S., Lopez-Bellido, R.F., Lopez-Bellido, L., MunozRomero, V., Moreno, F., Murillo, J.M., Franzluebbers, A.J., 2012. Stratification ratios in a rainfed Mediterranean Vertisol in wheat under different tillage, rotation and $\mathrm{N}$ fertilization rates. Soil and Tillage Research 119, 7-12.

Mikha, M.M., Rice, C.W., 2004. Tillage and manure effects on soil and aggregate associated carbon and nitrogen. Soil Science Society of America Journal 68, 809-816.

Mohanty, A., Mishra, K.N., Roul, P.K., Dash, S.N., Panigrahi, K.K., 2015. Influence of conservation agriculture production system on soil organic carbon, bulk density and waters table aggregates in a tropical rainfed agro ecosystem. Ecology, Environment and Conservation 21(4), 111-114.

Plaza-Bonilla, D., Cantero-Martinez, C., Vinas, P., AlvaroFuentes, J., 2013. Soil aggregation and organic carbon protection in a no-tillage chronosequence under Mediterranean conditions. Geoderma 193, 76-82.

Six, J., Elliott, E.T., Paustian, K., 2000a. Soil macroaggregate turn over and microaggregate formation: a mechanism for $\mathrm{C}$ sequestration under no-tillage agriculture. Soil Biology and Biochemistry 32, 2099-2103.

Six, J., Guggenberger, G., Paustian, K., Haumaier, L., Elliott, E.T., Zech, W., 2002. Sources and composition of soil organic matter fractions between and within soil aggregates. European Journal of Soil Science 52, $607-618$

Walkley, A. and Black, I.A., 1934. An examination of the Degtjareft method for determining soil organic matter and a proposed modification of the chromic acid titration method. Soil Science 37, 29-38.

Zotarelli, L., Alves, B.J.R., Urquiaga, S., Boddey, R.M., Six, J., 2007. Impact of tillage and crop rotation onlight fraction and intra-aggregate soil organic matter in two Oxisols. Soil and Tillage Research 95, 196-206. 